\title{
FATTY ACID COMPOSITION AND NATURAL ANTIOXIDANT CAPACITY OF TEN SERBIAN LINSEED CULTIVARS
}

\author{
Dušica S. Čolović ${ }^{\star}$, Janoš J. Berenji ${ }^{2}$, Alenka R. Levart ${ }^{3}$, Janez K. Salobir ${ }^{3}$, Jovanka D. Lević ${ }^{1}$, Radmilo \\ R. Čolović ${ }^{1}$, Sanja J. Popović ${ }^{1}$ \\ ${ }^{1}$ Institute of Food Technology, University of Novi Sad, Bulevar cara Lazara 1, 21000 Novi Sad, Serbia \\ ${ }^{2}$ Institute of Field and Vegetable Crops, Alternative Crops Department,21000 Novi Sad, Serbia \\ ${ }^{3}$ Biotechnical Faculty, University of Ljubljana,Groblje 3, SI-1230 Domžale, Slovenia
}

\author{
Corresponding author: \\ Phone: +381214853808 \\ Fax: +38121450725 \\ E-mail address: dusica.colovic@fins.uns.ac.rs
}

\begin{abstract}
Literature data about nutritional characteristics of linseed cultivars from some specific geographical area or country is scarce. For that very reason, following paper is presenting fatty acid (FA) compositions and antioxidant capacity of lipid-soluble (ACL) components of ten native linseed cultivars from Serbia. These characteristics can be interesting, especially due to the increasing trend of linseed usage in human diet. Presented results show that there were statistically significant $(p<0.05)$ differences between linseed kernels in FA composition. Negative correlation was found between FA C18:0 and $\alpha$ linolenic acid (ALA). The cultivar with the highest ACL value was No. 10 (342.66 $\mu \mathrm{mol}$ trolox/kg d.m.), meaning that it had very strong protection against oxidation of polyunsaturated FAs. Nevertheless, correlation between $\mathrm{ACL}$ and polyunsaturated FA content in cultivars was not statistically significant $(p=0.84)$. ACL of the samples did not depend on FA composition of linseed, but it might depend on characteristics of a specific cultivar. The aforementioned results show potential usage in storage of linseeds or its products, while FA composition of linseed kernels might be one of criteria for authentication of linseed origin, and can be of great help in future selection of the cultivars, depending on purpose of linseed production.
\end{abstract}

Key words: linseed, native cultivars, fatty acid, antioxidant capacity

\section{INTRODUCTION}

Not so many commercial crops are so intensively exploited during the history such as linseed. In fact, its Latin name (Linum usitatissimum) means "useful." It was primarily grown (about 3000 B.C.) for medicinal purposes and for the fibres of which were made linen. Nowadays, linseed oil is mainly used, whether it comes to food or chemical industry (Bhatty and Cherdkiatgumchai, 1995). This plant grows to a height up to $60 \mathrm{~cm}$, with slim and very fibrous stems, leaves with three veins, and its light blue flowers. The seeds are rich source of both edible and non-edible oils (Rubilar et al., 2010; Matheson, 1976), containing approximately $40 \%$ of oil, of which more than $70 \%$ are unsaturated fatty acids (FAs). In addition to a large amount of oil, linseed contains approximately $20-30 \%$ of crude protein (Ivanov et al., 2012a; Daun et al., 2003; Karlović and Andrić, 1996).

Raw linseed oil is dark yellow in colour, with strong specific smell and taste (Dimić, 2005). This oil is well known as one of the most unsaturated vegetable oils with high content of ALA, which amount in total fat is more than $50 \%$ (Gunstone, 2001). ALA is a precursor of eicosapentaenoic (EPA) and docosahexaenoic acid (DHA), n-3 polyunsaturated FAs, responsible for the proper brain development in children, as well as for resistance to various allergies, autoimmune 
diseases, cardiovascular problems, and inflammation (Sierra et al., 2008). These FAs are essential, because mammals, and therefore humans, cannot endogenously synthesize them and must adopt them exogenously from dietary sources (Beare Rogers, 2001). High quality of linseed oil confirms the fact that US National Cancer Institute ( $\mathrm{NCl}$ ) targeted linseed as one of the six plant materials for study as cancer-preventative foods. Linseed oil is a potent inhibitor of pro-inflammatory mediators even when used in domestic food preparation. This is a great advantage of linseed oil, which make it suitable for application in the development of novel anti-inflammatory therapies with or without pharmaceutical products for target populations (Oomah, 2001).

There are a lot of examples of positive linseed effects on animal health and wellbeing. The immunomodulating effects of omega-3 FAs combined with the potential hormonal effects of the phytoestrogens may have a positive effect on sow productivity and the health of the piglets. Due to the positive impact of including omega-3 FAs in human diets, there is significant interest in enriching the omega-3 FA content of meat products produced by beef cattle and swine. Linseed can be included in poultry diets if used in the proper proportions and formulated appropriately. The most popular commercial poultry product is omega-3 eggs (Newkirk, 2008).

The aim of this study was to determine FA composition and ACL of ten autochthonous linseed cultivars cultivated in the northern Serbian province Vojvodina, in order to detect some mutual characteristics, and to determine whether any significant variation existed in their compositions.

\section{MATERIAL AND METHODS}

\section{Material}

Examined cultivars of linseeds were developed at the Institute of Field and Vegetable Crops in Novi Sad, Department for Alternative Crops in Bački Petrovac, Serbia. The cultivars were labelled with number from 1 to 10. All of them were cultivated in Vojvodina, the northern Province of Serbia. After harvesting, grains were transported to the laboratory in polypropylene bags and held at room temperature. They were clea- ned on an air screen cleaner to remove all foreign matter and impurities such as dust, dirt and immature and broken kernels.

\section{Fatty acid analysis}

Supercritical fluid extraction (SFE) with $\mathrm{CO}_{2}$ was used for extraction of lipids from the samples, since it showed good results as a preparative technique for FA analysis. Extraction was performed on LECO TFE-2000 fat analyzer and extraction conditions were adjusted as explained in the paper of Ivanov et al. (2012b). FA methyl esters were prepared from the extracted lipids by transmetilation method that use $14 \%$ wt. boron trifluoride/methanol solution, as recommended method for this type of substrates (Ivanov et al., 2012b; Karlović and Andrić, 1996). Nitrogen gas (99.99\%) was used for removing boron trifluoride/methanol solution and $n$-heptane (99.99\%) from FA methyl esters. Obtained samples were analyzed by a gas chromatograph Agilent 7890A system (Agilent Technologies, Santa Clara, CA, USA) with flame ionization detector (GC-FID), auto-injection module for liquid, equipped with fused silica capillary column (DB-WAX $30 \mathrm{~m}, 0.25 \mathrm{~mm}, 0.50 \mathrm{um}$ ). Carrier gas was helium (purity $>99.9997$ vol $\%$, flow rate $=1.26 \mathrm{ml} / \mathrm{min}$ ). The FAs peaks were identified by comparison of retention times with retention times of standards from Supelco 37 component FA methyl ester mix and with data from internal data library, based on previous experiments and FA methyl ester determination on GC-MS. Results were expressed as mass of single FA or FA group $(\mathrm{g})$ in $100 \mathrm{~g}$ of total FAs (relative content).

\section{Antioxidant capacity of lipid-soluble substances analysis}

Estimation of the antioxidant capacity in lipid-soluble substances (ACL) was done by photochemiluminescence method using an antioxidant analyser Photochem instrument (Jena Analitik, Germany). In the ACL assay, the photochemical generation of free radicals was measured with a sensitive detector by using chemiluminescence. Free radicals were produced from the luminol, which worked partly as a photosensitizer and partly as an oxygen radical detection reagent. The lipid-soluble antioxidants were measured with the ACL kit, according to 
manufacturer's protocol (Jena Analytik, 2004). The working solution consisted of the following reagents:

methanol (Reagent 1) - $2.3 \mathrm{ml}$,

buffer solution (Reagent 2) - $200 \mu \mathrm{l}$,

photosensitizer (Reagent 3) $-25 \mu \mathrm{l}$.

Antioxidant capacities of the samples were determined from calibration curve by extrapolation method. Trolox standard with the concentration of $100 \mu \mathrm{mol} / \mathrm{dm}^{3}$ was used for the preparation of calibration curve. All measurements were done in duplicates.

\section{Statistical analysis}

Statistical analysis of experimental data was performed using STATISTICA software version 10 (Statsoft, Tulsa, OK, USA). One way analysis of variance - ANOVA and Tukey's HSD comparison of means of samples were used for analysing variations. Differences among means with probability $p \leq 0.05$ were accepted as representing statistically significant differences. Correlations between FAs and ACL pairs were evaluated at $p \leq 0.05$.

\section{RESULTS AND DISCUSSION}

FA composition of linseed is well known, however, there are some differences among various cultivars, geographical area, climatic conditions, etc. Table 1 presents FA composition of ten cultivars, examined in this experiment. Obviously, FA composition of linseed oil is dominated by unsaturated C18
FAs (average contents: C18:1 - 22.5\%, C18:2 - 14.46\%, ALA - 53.23\%). Bean and Leeson (2002) reported following mean percentages for these FAs: C18:1 $18.50 \%$, C18:2 - $14.44 \%$ and ALA $57.11 \%$. Myristic acid (C14:0) was not detected in all samples, and when detected, did not exceed $0.06 \%$. Sauvant et al. (2004) also showed low content of this FA $(0.10 \%)$, while Bean and Leeson (2002) did not detected it.

Cultivar 1 had significantly $(p \leq 0.05)$ higher content of saturated FAs (SFA), which accounted for $24.01 \%$ of total FAs, in contrast to all other cultivars having from $9.23 \%$ to $12.11 \%$ of total FAs. Content of monounsaturated FAs (MUFA) ranged from 16.44\% (cultivar 5 ) to $22.57 \%$ (cultivar 8 ). Bayrak et al. (2010) reported in their paper average SFA content of $10.02 \%$ and MUFA content of $22.47 \%$. Looking at content of polyunsaturated FAs (PUFA), it can be seen that cultivar 1 had significantly lower $(p \leq 0.05)$ PUFA content $57.79 \%$ than all other cultivars, while cultivar number 5 had significantly higher $(p \leq 0.05) \quad$ PUFA content (74.33\%).

Another interesting fact is that C18:0 FA had significant $(p \leq 0.05)$ negative effect $(r=-$ 0.86 ) on the content of essential ALA (see Table 2). It means that with the increase of C18:0 FA content, content of ALA generally decrea-sed, which was especially obvious in cultivar 1 , as already mentioned.

Table 1.

Fatty acid composition of extracted linseed oils

\begin{tabular}{cllllllllll}
\hline \multirow{2}{*}{$\begin{array}{c}\text { Linseed } \\
\text { cultivar }\end{array}$} & \multicolumn{8}{c}{ Fatty acid content (\% of total fatty acids) } \\
\cline { 2 - 11 } & $\mathbf{C 1 4 : 0}$ & $\mathbf{C 1 6 : 0}$ & $\mathbf{C 1 6 : 1}$ & $\mathbf{C 1 8 : 0}$ & $\mathbf{C 1 8 : 1}$ & $\mathbf{C 1 8 : 2} \mathbf{n - 6}$ & $\mathbf{C 1 8 : 3} \mathbf{n - 3}$ & SFA & MUFA & PUFA \\
\hline 1 & 0.00 & $4.58^{\mathrm{a}}$ & $0.20^{\mathrm{a}}$ & $19.43^{\mathrm{a}}$ & $17.99^{\mathrm{b}}$ & $14.83^{\mathrm{a}}$ & $42.97^{\mathrm{c}}$ & $24.01^{\mathrm{a}}$ & $18.20^{\mathrm{ab}}$ & $57.79^{\mathrm{a}}$ \\
2 & 0.00 & $4.89^{\mathrm{a}}$ & $0.08^{\mathrm{a}}$ & $5.96^{\mathrm{b}}$ & $20.77^{\mathrm{ab}}$ & $16.17^{\mathrm{a}}$ & $52.12^{\mathrm{b}}$ & $10.85^{\mathrm{b}}$ & $20.85^{\mathrm{a}}$ & $68.30^{\mathrm{b}}$ \\
3 & 0.00 & $4.93^{\mathrm{a}}$ & $0.07^{\mathrm{a}}$ & $5.82^{\mathrm{b}}$ & $20.30^{\mathrm{ab}}$ & $15.88^{\mathrm{a}}$ & $52.99^{\mathrm{b}}$ & $10.76^{\mathrm{b}}$ & $20.38^{\mathrm{a}}$ & $68.87^{\mathrm{b}}$ \\
4 & 0.00 & $5.31^{\mathrm{a}}$ & $0.08^{\mathrm{a}}$ & $4.08^{\mathrm{b}}$ & $21.03^{\mathrm{ab}}$ & $15.29^{\mathrm{a}}$ & $54.22^{\mathrm{a}}$ & $9.39^{\mathrm{b}}$ & $21.11^{\mathrm{a}}$ & $69.51^{\mathrm{b}}$ \\
5 & 0.00 & $5.42^{\mathrm{a}}$ & $0.11^{\mathrm{a}}$ & $3.81^{\mathrm{b}}$ & $16.33^{\mathrm{b}}$ & $13.27^{\mathrm{a}}$ & $61.06^{\mathrm{a}}$ & $9.23^{\mathrm{b}}$ & $16.44^{\mathrm{b}}$ & $74.33^{\mathrm{c}}$ \\
6 & $0.05^{\mathrm{a}}$ & $5.75^{\mathrm{a}}$ & $0.07^{\mathrm{a}}$ & $4.32^{\mathrm{b}}$ & $20.94^{\mathrm{ab}}$ & $13.34^{\mathrm{a}}$ & $55.52^{\mathrm{a}}$ & $10.13^{\mathrm{b}}$ & $21.06^{\mathrm{a}}$ & $68.86^{\mathrm{b}}$ \\
7 & $0.05^{\mathrm{a}}$ & $6.29^{\mathrm{a}}$ & $0.13^{\mathrm{a}}$ & $5.78^{\mathrm{b}}$ & $21.72^{\mathrm{ab}}$ & $13.16^{\mathrm{a}}$ & $52.87^{\mathrm{b}}$ & $12.11^{\mathrm{b}}$ & $21.91^{\mathrm{a}}$ & $66.03^{\mathrm{b}}$ \\
8 & $0.05^{\mathrm{a}}$ & $5.91^{\mathrm{a}}$ & $0.09^{\mathrm{a}}$ & $4.32^{\mathrm{b}}$ & $22.43^{\mathrm{a}}$ & $14.91^{\mathrm{a}}$ & $52.29^{\mathrm{b}}$ & $10.27^{\mathrm{b}}$ & $22.57^{\mathrm{a}}$ & $67.20^{\mathrm{b}}$ \\
9 & $0.06^{\mathrm{a}}$ & $6.42^{\mathrm{a}}$ & $0.15^{\mathrm{a}}$ & $3.65^{\mathrm{b}}$ & $21.02^{\mathrm{ab}}$ & $13.36^{\mathrm{a}}$ & $55.35^{\mathrm{a}}$ & $10.13^{\mathrm{b}}$ & $21.23^{\mathrm{a}}$ & $68.70^{\mathrm{b}}$ \\
10 & $0.05^{\mathrm{a}}$ & $5.71^{\mathrm{a}}$ & $0.08^{\mathrm{a}}$ & $4.78^{\mathrm{b}}$ & $22.02^{\mathrm{a}}$ & $14.44^{\mathrm{a}}$ & $52.92^{\mathrm{b}}$ & $10.53^{\mathrm{b}}$ & $22.16^{\mathrm{a}}$ & $67.36^{\mathrm{b}}$ \\
Mean & 0.05 & 6.09 & 0.12 & 6.74 & 22.55 & 14.46 & 53.23 & 11.74 & 20.59 & 67.69 \\
\hline
\end{tabular}

The values are presented as mean, $\mathrm{n}=3$

a-c Different superscripts within the same column indicate significant differences $(p \leq 0.05)$ 
Table 2.

Correlation coefficients between fatty acids of various linseed cultivars

\begin{tabular}{cccccccc}
\hline & C14:0 & C16:0 & C16:1 & C18:0 & C18:1 & C18:2 & C18:3 n-3 \\
\hline C14:0 & 1 & & & & & & \\
C16:0 & $0.883^{*}$ & 1 & & & & & \\
C16:1 & -0.03 & -0.06 & 1 & & & & \\
C18:0 & -0.36 & -0.60 & $0.751^{*}$ & 1 & & & \\
C18:1 & $0.644^{*}$ & 0.499 & -0.44 & -0.41 & 1 & & \\
C18:2 & -0.59 & $-0.71^{*}$ & -0.29 & 0.20 & 0.148 & 1 & \\
C18:3 n-3 & 0.139 & 0.462 & -0.54 & -0.86 & -0.10 & -0.43 & 1 \\
\hline
\end{tabular}

Statistically significant correlation $(p \leq 0.05)$

Significant negative correlation was found also bet-ween $\mathrm{C} 18: 2$ and $\mathrm{C} 16: 0 \quad(r=-0.71)$, while $\mathrm{C} 14: 0$ and $\mathrm{C} 16: 0$ were in significant positive correlation $(r=0.883)$.

The FA composition of seed oils varies widely among different species. Usually, the occurrence of some specific FAs is characteristic for particular plant families (Aitzetmüller, 1996; Özcan et al., 2010). The most dominant FA in all examined linseed cultivars was ALA, with mean value of $53.23 \%$ (see Table 3). The highest content of this FA was recorded in cultivar number 5 $(61.06 \%)$. Cultivar 1 significantly differed $(p \leq 0.05)$ from all other samples by being lower in the content of ALA (42.97\%). It is noticeable that this cultivar contained significantly $(p \leq 0.05)$ higher content of C18:0 $F A$, which was present in the amount of $19.43 \%$. By comparing the obtained results with those presented in paper of Bayrak et al. (2010), the difference in FA compositions is evident. In the aforementioned paper, authors did not detect $\mathrm{C} 14: 0$ and $\mathrm{C} 16: 1$ FAs, while detecting C20:0 and C20:1. Bean and Leeson (2002) reported results more similar to ours, except for absence of C14:0 FA. Specific FA composition of examined Serbian cultivars might be used as one of the benchmarks for authentication of linseed origin.

As shown in the paper of Bean and Leeson (2002), mean PUFA content of 23 examined linseed samples was $71.55 \%$, which is in accordance with our results. However, ElBeltagi et al. (2007) reported lower valuesfor PUFA content $(66.5 \%)$ in five linseed cuItivars from Egypt. FA composition of linseed oil especially composition of unsaturated FAs and their content highly depends on climatic conditions. Early and late frosts, as well as high temperatures and drought damage kernels, is causing higher content of palmitic (C16:0), linoleic (C18:2) and ALA than it is in whole and undamaged kernels (Sediqi, 2012; Hall et al., 2006). Cool climatic conditions characteristic for northern regions increase the contents of linoleic acid and ALA (Nykter and Kymäläinen, 2006). High humidity conditions extend accumulation period of unsaturated fatty acids (Laza and Pop, 2012).

$\mathrm{N}-6 / \mathrm{n}-3$ ratio in the linseed grains ranged from 0.22 (cultivar 5) to 0.35 (cultivar 1 ), as presented in Figure 1. Western diets are deficient in n-3 FAs, while having extortionate amounts of n-6 FAs in comparison with the diet on which humans evolved. Recommended values of $n-6 / n-3$ ratio should be at least less than $4 / 1$ in the secondary prevention of cardiovascular disease, and a ratio of 2-3/1 suppressed inflammation in patients with rheumatoid arthritis (Simopoulos, 2004; Scollan et al., 2006). FA composition of all investigated cultivars can be considered as nutritionally desirable. Although there were significant differences in $n-6 / n-3$ ratio between the cultivars, all values were far below 2-3/1.

The significance of lipid soluble antioxidants is crucial in protection of lipid-rich food from fast oxidative deterioration. Since linseed is an oilseed, ACL was chosen as an appropriate criterion for determination of antioxidant capacity in linseed kernels, and the results are presented in Table 3.

The highest ACL was recorded in cultivar 10 (342.66 $\mu \mathrm{mol}$ trolox/kg d.m.), and the lowest in cultivar 4 (136.44 $\mu \mathrm{mol}$ trolox/kg d.m.). The ACL values varied over a wide range and significant differences $(p \leq 0.05)$ were observed among the cultivars (see Table 3 ). 


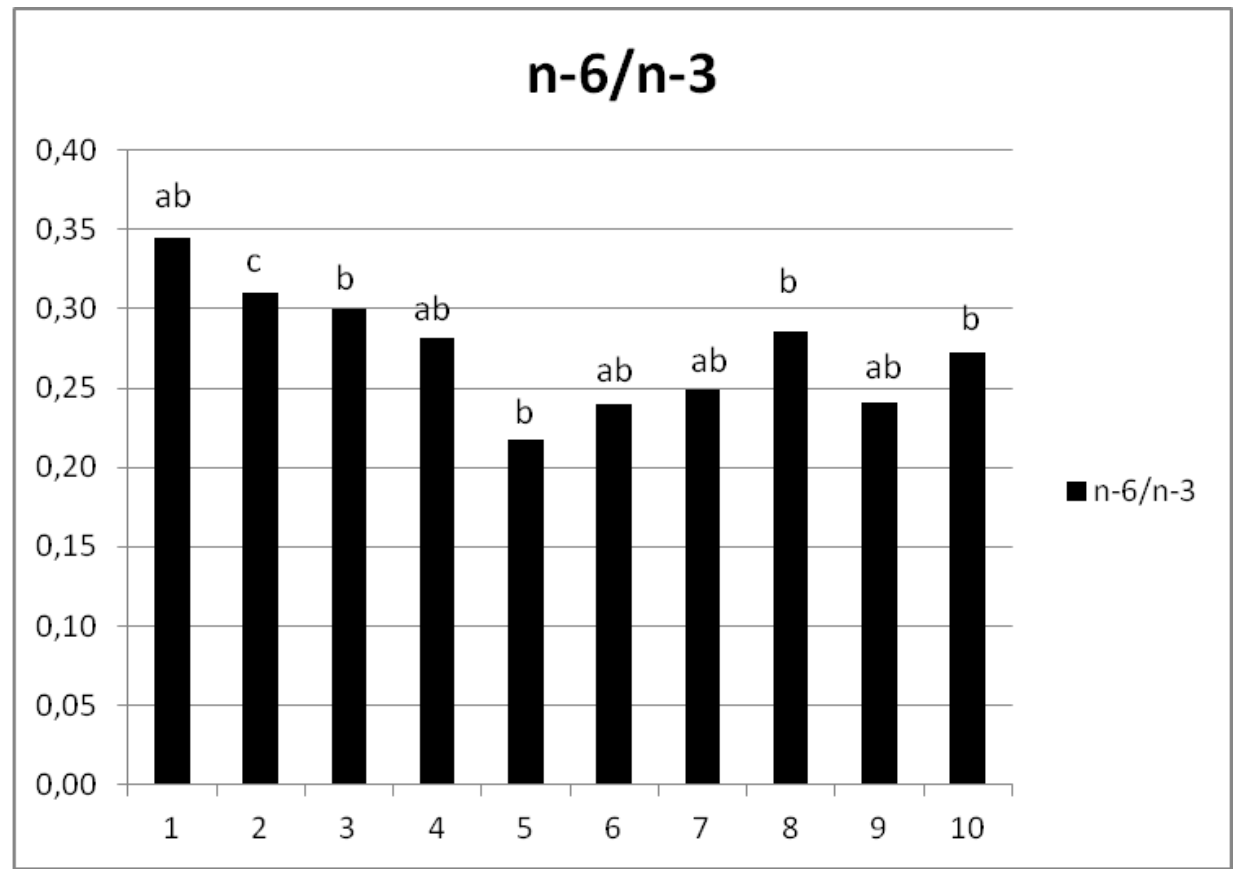

Figure 1. Ratio of $n-6$ and $n-3$ fatty acids in the investigated cultivars

Table 3.

Antioxidant capacity of lipid-soluble substances in linseed kernels

\begin{tabular}{cccc}
\hline $\begin{array}{c}\text { Linseed } \\
\text { cultivar }\end{array}$ & $\begin{array}{c}\text { ACL } \\
(\boldsymbol{\mu m o l} \text { trolox/kg d.m.) }\end{array}$ & SD & CV \\
\hline 1 & $260.14^{\mathrm{bcd}}$ & 16.52 & 6.35 \\
2 & $273.32^{\mathrm{cd}}$ & 9.23 & 3.38 \\
3 & $273.55^{\mathrm{cd}}$ & 6.33 & 2.31 \\
4 & $136.44^{\mathrm{a}}$ & 6.38 & 5.00 \\
5 & $259.96^{\mathrm{bcd}}$ & 8.64 & 3.32 \\
6 & $199.26^{\mathrm{ab}}$ & 9.59 & 4.81 \\
7 & $266.28^{\mathrm{cd}}$ & 5.22 & 1.96 \\
8 & $250.68^{\mathrm{bc}}$ & 4.50 & 1.80 \\
9 & $227.65^{\mathrm{bc}}$ & 4.76 & 2.09 \\
10 & $342.66^{\mathrm{etg}}$ & 10.45 & 3.05 \\
\hline Mean & 248.99 & & \\
\hline
\end{tabular}

The values are presented as mean, $n=3$

${ }^{a-g}$ Different superscripts within the same column indicate significant differences $(p \leq 0.05)$, SD - standard deviation. $\mathrm{CV}$ - coefficient of variation

The cultivars with higher ACL value had stronger protection against oxidation of PUFA. However, statistically significant correlation between ACL and PUFA, or ALA content in the cultivars could not be found. Correlation coefficient between $\mathrm{ACL}$ and PUFA content was $r=0.04$, with $p=0.84$, while $r=0.006$ between ACL and ALA, with $\mathrm{p}=0.99$.

The highest PUFA content was recorded in cultivar 5 (Table 3). Nevertheless, ACL value for this cultivar was $259.96 \mu \mathrm{mol}$ trolox/kg d.m. (Table 3), which was close to the mean ACL value $(248.99 \mu \mathrm{mol}$ trolox $/ \mathrm{kg}$ d.m.). Cultivar 10 had the highest ACL value, as already mentioned, but this cultivar had PUFA content of $67.36 \%$ (mean was $67.66 \%$ ) and ALA content of $52.92 \%$ (mean was $53.62 \%$ ). It can be concluded that ACL did not depend on the FA composition of linseed, but it might depend on characteristics of a specific cultivar.

\section{CONCLUSIONS}

Our results showed that the examined Serbian linseed cultivars contained FA C14:0, which is not frequently present in the FA composition of linseed. Therefore, it might 
be a specificity of linseed oil originated from this specific geographical area. FA C18:0 and ALA were in significant negative correlation $(r=-0.86)$, meaning that with an increase in C18:0 content, ALA content decreased, and vice versa. The highest ACL was recorded in cultivar 10 (342.66 $\mu \mathrm{mol}$ trolox/kg d.m.), and the lowest in cultivar 4 (136.44 $\mathrm{mmol}$ trolox $/ \mathrm{kg}$ d.m.). However, any significant correlation between $\mathrm{ACL}$ and content of any FA was not found, which might lead to conclusion that $A C L$ is dependent on linseed cultivar, rather than FA composition.

\section{ACKNOWLEDGEMENTS}

The authors are thankful to the Serbian Ministry of Education, Science and Technological Development for financial support Project No. III 46012. Presented results are also a part of the Project of bilateral cooperation between the Republic of Slovenia and the Republic of Serbia "Influence of thermal treatments on antioxidative capacity, oxidative stability and nutritive value of animal feed".

\section{REFERENCES}

1. Aitzetmüller K. (1996). An unusual fatty acid pattern in Eranthis seed oil. Lipids, 31 (2), 201-205

2. Bayrak, A., Kiralan, M., Ipek, A., Arslan, N., Cosge, B., Khawar, K.M. (2010). Fatty Acid Compositions of Linseed (Linum Usitatissimum L.) Genotypes of Different Origin Cultivated in Turkey. Biotechnology and Biotecnological Equipment, 24 (2), 1836-1842.

3. Bean, L. D., Leeson, S. (2002). Fatty acid profiles of 23 samples of flaxseed collected from commercial feed mills in Ontario. Journal of Applied Poultry Research, 11, 209-211.

4. Beare - Rogers, J., Dieffenbacher, A., Holm, J.V. (2001). Lexicon of lipid nutrition (IUPAC Technical report). Pure and Applied Chemistry, 73 (4), 685-744.

5. Bhatty, R., Cherdkiatgumchai, P. (1990). Compositional analysis of laboratory-prepared and commercial samples of linseed meal and hulls isolated from flax. Journal of American Oil Chemists Society, 67, 79-84.

6. Daun, J.K., Barthet V. J., Chornick T.L., Duguid, S. (2003). Structure, composition, and variety development of flaxseed In Flaxseed in human nutrition. Eds. L.U. Thompson, Cunnane, AOAC Press, Champaign, IL, pp. $1-40$.

7. Dimić, E. (2005). Hladno ceđena ulja. Tehnološki fakultet, Novi Sad.

8. El-Beltagi, H.S., Salama, Z.A., El-Hariri, D.M. (2007). Evaluation of fatty acids profile and the content of some secondary metabolites in seeds of different flax cultivars (Linum usitatissimum L.). General and Applied Plant Physiology, 33 (3-4), 187-202.

9. Gunstone, F. (2001). Oilseed crops with modified fatty acid composition. Journal of Oleo Science, 50 (5), $269-279$.

10. Hall, C. III, Tulbek, M. C., Xu, Y. (2006). Flaxseed. Advances in Food Nutrition Research, 51, 1-97.

11. Ivanov, D., Kokić, B., Brlek, T., Čolović, R., Vukmirović, Đ., Lević, J., Sredanović, S. (2012a). Effect of microwave heating on content of cyanogenic glycosides in linseed. Ratarstvo $i$ povrtarstvo, 49 (1), 63-68.

12. Ivanov, D., Čolović, R., Lević, J., Sredanović, S. (2012b). Optimization of supercritical fluid extraction of flaxseed oil using RSM. European Journal of Lipid Science and Technology, 114 (7), 807-815.

13. Jena Analytik. (2004). Determination of the antioxidative capacity (water soluble - ACW and lipid soluble - ACL) in PUFA Oil. Reference No.: BS_PLC_09_04_e|07/2004|Öz.

14. Karlović, Đ., Andrić, N. (1996). Kontrola kvaliteta semena uljarica. Tehnološki fakultet, Novi Sad, Savezni zavod za standardizaciju, Beograd, Srbija.

15. Laza, A., Pop, G. (2012). The influence of fertilization and seeding density on flax oil production quality. Research Journal of Agricultural Science, 44 (4), $96-102$.

16. Matheson E.M. (1976). Linseed. In Vegetable Oil Seed Crops in Australia. Ed. Matheson, E.M., Holt, Rinehart, \&Winston, Sydney, Australia, pp. $111-121$.

17. Newkirk, R. (2008). Flax Feed Industry Guide. Flax Canada, Winnipeg, Manitoba, Canada.

18. Nykter, M., Kymäläinen, H.-R. (2006). Quality characteristics of edible linseed oil. Agricultural and Food Science, 15, $403-412$

19. Oomah, D. (2001). Flaxseed as a functional food source. Journal of the Science of Food and Agriculture, 81, 889 - 894.

20. Özcan, M.M., Cesari, İ., Arslan, D. (2010). Physicochemical properties, fatty acid and mineral content of some walnuts (Juglans regia L.) types. Agricultural Sciences, 1, 62-67.

21. Rubilar, M., Gutiérrez, C., Verdugo, M., Shene, C., Sineiro, J. (2010). Flaxseed as a source of functional ingredients. Journal of Soil Science and Plant Nutrition, 10 (3), 373 - 377.

22. Sauvant, D., Perez, J.-M., Tran, G. (2004). Table of Composition and Nutritional Value of Feed Materials. Wageningen Academic Publishers The Nederlands and INRA, Paris, France.

23. Scollan, N., Dhanoa, M.S., Choi, N.J., Maeng, W.J., Enser, M., Wood, J.D. (2001). Biohydrogenation and digestion of long chain fatty acids in steers fed on different sources of lipid. Journal of Agricultural Science, 136, 345-55.

24. Sediqi, M.N. (2012). Adaptabilty of Oilseed Species at High Altitudes of Colorado and Technology Transfer to Afghanistan. MSc Thesis, Colorado State University, Fort Collins, Colorado. 
25. Sierra, S., Lara-Villoslada, F., Comalada, M., Olivares, M., Xaus, J. (2008). Dietary eicosapentaenoic acid and docosahexaenoic acid equally incorporate as decosahexaenoic acid but differ in inflammatory effects. Nutrition, 24, 245 - 254.

26. Simopoulos, A.P. (2002). The importance of the ratio of omega-6/omega-3 essential fatty acids. Biomedicine and Pharmacotherapy 56, 365-379.

\title{
САСТАВ МАСНИХ КИСЕЛИНА И ПРИРОДАН АНТИОКСИДАТИВНИ ПОТЕНЦИЈАЛ ДЕСЕТ СОРТИ ЛАНЕНОГ СЕМЕНА ИЗ СРБИЈЕ
}

\author{
Душица С. Чоловић ${ }^{1 *}$, Јанош Ј. Берењи ${ }^{2}$, Аленка Р. Леварт ${ }^{3}$, Јанез К. Салобир ${ }^{3}$, \\ Јованка Д. Левић ${ }^{1}$, Радмило Р. Чоловић ${ }^{1}$, Сања Ј. Поповић ${ }^{1}$ \\ ${ }^{1}$ Универзитет у Новом Саду, Научни институт за прехрамбене технологије у Новом Саду, \\ 21000 Нови Сад, Булевар цара Лазара бр. 1, Србија \\ ${ }^{2}$ Институт за ратарство и повртарство, Одељење за алтернативне културе, \\ 21000 Нови Сад, Максима Горког 30, Србија \\ ${ }^{3}$ Универзитет у Љубљани, Биотехнички фракултет, Домжале, Гробље 3, Словенија
}

Сажетак: Литературни подаци о нутритивним карактеристикама различитих сорти ланеног семена са истог географског подручја су изузетно малобројни. Стога је тематика овог рада посвећена испитивању маснокиселинског састава и антиоксидативног капацитета компонената растворљивих у уљу код десет аутохтоних сорти ланеног семена из Србије. Поменуте особине нарочито су занимљиве, с обзиром на растући тренд употребе лана у људској исхрани. Добијени резултати показали су да су се маснокиселински састави испитиваних сорти међусобно статистички значајно разликовали $(p<0.05)$. Између масних киселина C18:0 и а-линоленске киселине (АЛА) утврђена је негативна корелација. Сорта са највишим антиоксидативним капацитетом (АЦЛ=342.66 $\mu \mathrm{mol}$ trolox $/ \mathrm{kg}$ С.м.) је била означена бројем 10, што значи да је ова сорта показала изузетну могућност самозаштите од аутооксидације полинезасићених масних киселина (ПУФА). Међутим, корелација између садржаја ПУФА и АЦЛ није била статистички значајна ( $p=0.84)$. Стога је закључено да АЦЛ испитиваних узорака не зависи од маснокиселинског састава, него од специфичних карактеристика одређене сорте. Приказани резултати показују значај и потенцијал примене у контроли складиштења ланеног семена и његових производа, док се маснокиселински састав може употребити као један од критеријума за одређивање географског порекла, или у селекцији сорти лана у зависности од сврхе узгоја.

Кључне речи: ланено семе, аутохтоне сорте, масне киселине, антиоксидативни капацитет

Received: 17 June 2015

Accepted: 27 August 2015 